\title{
Growth dynamics within bacterial communities in riverine and estuarine batch cultures
}

\author{
Silke Langenheder ${ }^{1, *}$, Veljo Kisand ${ }^{2,3}$, Eva S. Lindström ${ }^{1,4}$, Johan Wikner ${ }^{2}$, \\ Lars J. Tranvik ${ }^{1}$ \\ ${ }^{1}$ Department of Limnology, Evolutionary Biology Centre, Uppsala University, 75236 Uppsala, Sweden \\ ${ }^{2}$ Umeå Marine Sciences Centre, Norrbyn, 91020 Hörnefors, Sweden \\ ${ }^{3}$ Present address: Institute for Chemistry and Biology of the Marine Environment (ICBM), University of Oldenburg, \\ 26111 Oldenburg, Germany \\ ${ }^{4}$ Present address: Département des sciences biologiques, Université du Québec à Montréal, Montréal H3C 3P8, Canada
}

\begin{abstract}
We investigated temporal changes in community composition of bacteria growing on riverine dissolved organic carbon. Batch cultures were adjusted to riverine or estuarine salinity levels and inoculated with bacteria from these 2 environments to test whether growth patterns of bacterial taxa are influenced by salinity and/or the source of the inoculum. Changes in bacterial community composition at different stages of the growth phase were studied by 16S rDNA denaturing gradient gel electrophoresis (DGGE). Furthermore, the growth dynamics of 7 bacteria previously isolated from the estuary were followed by quantitative DNA-DNA hybridization. Growth dynamics within bacterial communities were significantly influenced by the source of the inoculum but not by salinity, suggesting that slight changes in salinity, to which riverine bacteria are exposed when discharged into the Northern Baltic Sea, are not a major regulating factor of community dynamics. Additionally, our results indicated only minor differences in the appearance and growth of bacteria when examined by quantitative DNA-DNA hybridization, whereas DGGE banding patterns suggested that there were fast- and slow-growing types of bacteria.
\end{abstract}

KEY WORDS: Heterotrophic bacteria · Growth dynamics · Batch cultures · DGGE · DNA-DNA hybridization

\section{INTRODUCTION}

Cycling of dissolved organic matter (DOM) within aquatic ecosystems is to a large extent studied in experiments in which DOM bioavaibility to bacterial communities is assessed without any information on community composition. Such studies reveal that, for example, only a minor part of the total dissolved organic carbon (DOC) pool is labile and easily utilized by bacteria (cf. Sondergaard \& Middelboe 1995 for a cross system comparison). However, we still lack information about the significance of bacterial species composition in the process of DOM degradation. Composition of DOM (van Hannen et al. 1999, Crump et al. 2003) as well as DOC concentration (Eiler et al. 2003) can affect various bacterial taxa differentially, and thereby alter bacterial community composition. In addition, different bacteria seem to be involved in the degradation of low molecular weight (LMW) and high molecular weight (HMW) DOC (Covert \& Moran 2001). Cottrell \& Kirchman (2000) showed that an affinity to certain size classes of DOM can occur on a very coarse phylogenetic level, since $\alpha$ Proteobacteria preferably utilized free amino acids whereas Cytophaga-Flavobacteria specialized on combined amino acids. All this suggests that substrate specialization occurs within bacterial communities, with different groups specializing on different components of the bulk DOM pool.

Bacteria preferentially utilize the most readily available components of the complex natural DOM, and 
hence these components are exhausted more rapidly than more recalcitrant substrates. Accordingly, Tranvik \& Höfle (1987) found a sequence of maximum utilization of glucose followed by a later maximum in phenol utilization during batch culture growth. It may be hypothesized that the gradual change in the composition of available carbon sources in mixed batch cultures results in a succession of bacteria, from those that respond rapidly to an initially high supply of available substrates, to those that grow more successfully when the supply of labile substrates is reduced. We tested this hypothesis using a batch culture approach to see if sequential patterns of population growth could be observed. DOM from a river in northern Sweden, which also comprises a significant fraction of the estuarine DOM pool (Zweifel et al. 1995), was used as a carbon source. The cultures were adjusted to riverine or estuarine salinity levels and inoculated with bacteria from these 2 environments. We studied changes in bacterial community composition at different stages of the bacterial growth phase by denaturing gradient gel electrophoresis (DGGE) of 16S rDNA. In addition, the growth dynamics of 7 bacteria previously isolated from the estuary were followed by quantitative DNA-DNA hybridization. The major goal was to investigate if different growth dynamics could be observed for taxa enriched in the cultures, and whether the growth patterns are influenced by environmental stress (i.e. a change in salinity) and/or the source of the inoculum.

\section{MATERIALS AND METHODS}

Sampling and experimental set-up. Water for the preparation of the DOM fraction was sampled in April 2000, during the spring flood, from the Öreälven river in northern Sweden at a location approximately $2 \mathrm{~km}$ upstream of the river mouth (Wikner et al. 1999). The river is not regulated, and drains a sparsely populated area dominated by mires and coniferous forests and contributes significantly to the organic matter loading of the Bothnian Bay (Pettersson et al. 1997). Spring flood water was selected as a carbon source for the culture experiment, because this major hydrological event is the largest input source of organic matter to the Baltic Sea (Bishop \& Pettersson 1996, Pettersson et al. 1997). The water was stored frozen at $-20^{\circ} \mathrm{C}$ until the experiment was set up 4 mo later. Prior to the start of the experiment, the water was thawed and filtered through $0.2 \mu \mathrm{m}$ Mini Filter capsules with a HT Tuffryn ${ }^{\circledR}$ Membrane (Gelman Sciences) using a peristaltic pump and Whatman Gamma 12 filter capsules (pore size 8 $\mu \mathrm{m})$ as a pre-filter. The filters were rinsed with approximately $4 \mathrm{l}$ of Milli-Q water and pressure was adjusted to yield a constant continuous flow through the capsule. Both filter units were changed frequently (after filtration of approx. 20 l). The filtered water was filled directly into acid-washed polycarbonate or polyethene bottles and stored at $4^{\circ} \mathrm{C}$ until inoculation (within $12 \mathrm{~h}$ ). DOC concentrations were similar before and after the filtration procedure, indicating that there was no unintended release of DOC from the filter capsules.

Water for preparation of the inoculum was sampled on September 1, 2000, directly before the start of the experiment. The riverine inoculum was prepared from surface water of the river site described above, and the estuarine inoculum from surface water sampled at Stn B3 in the Öre Estuary (Wikner \& Hagström 1999). In situ temperature was $14.2^{\circ} \mathrm{C}$ in the estuary and $13.1^{\circ} \mathrm{C}$ at the river site. $\mathrm{pH}$ was 7.01 at the river site and 8.46 in the estuary. Salinity at the estuarine site was $3 \%$ ( $1 \%$ \% 1 practical salinity unit). To generate bacterial inocula, $4 \mathrm{l}$ of water from each site were filtered through $142 \mathrm{~mm} \mathrm{GF} / \mathrm{F}$ filters (pre-combusted for $4 \mathrm{~h}$ at $450^{\circ} \mathrm{C}$ ) at low pressure. GF/F filtration excludes larger cells from the inoculum, but such filtration is in our experience the only effective way to prevent growth of flagellates in the cultures. There was no difference in DOC concentration determined in triplicate samples taken before and after the filtration, indicating that there was no unintended release of DOC during the filtering procedure.

Batch cultures of $15 \mathrm{l}$ were set up which differed according to the origin of the inoculum (riverine or estuarine bacteria) and salinity (riverine or estuarine conditions). Since the average salinity level in the Northern Baltic Sea is approximately $4 \%$, we adjusted the salinity in the estuarine cultures to this level. Four treatments were established with 3 replicates each: RIV 0\%o (riverine bacteria at $0 \%$ ); RIV 4\%o (riverine bacteria at $4 \%$ ); EST $0 \%$ (estuarine bacteria at $0 \%$ ); and EST $4 \%$ (estuarine bacteria at $4 \%$ ). As mentioned above, all cultures were based on the same riverine $0.2 \mu \mathrm{m}$ filtered DOM fraction. The adjustment to $4 \%$ salinity was done by the addition of $100 \times$ artificial, organic-free brackish water medium (Wikner et al. 1999). Since the addition of the brackish water medium accounted for a $4 \%$ dilution of the DOM in the bottles, we added the corresponding volume of Milli-Q water to the ' $0 \%$ ' treatments. Additionally, since the estuarine inoculum resulted in a slight increase in salinity, we adjusted salinity in all bottles receiving a riverine inoculum by addition of brackish water medium to the same salinity. As a result, the actual salinity in the ' $0 \%$ ' treatments increased from 0.01 to $0.09 \%$. The addition of an estuarine inoculum to the cultures resulted in a slight increase in $\mathrm{pH}$ from $7.26 \pm 0.15$ to $7.53 \pm 0.11$ (2-way ANOVA, $\mathrm{p}=0.016)$, but the addition of brackish water medium did not $(p=0.297)$. Nitrogen 


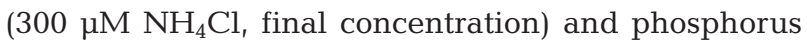
(100 $\mu \mathrm{M} \mathrm{Na}_{2} \mathrm{HPO}_{4}$, final concentration) were added to the cultures, resulting in carbon-limiting conditions. Finally, the inoculum $(500 \mathrm{ml})$ was added to the cultures. The experiment was run in the dark at $15^{\circ} \mathrm{C}$ for $300 \mathrm{~h}$. After this, bacteria had reached stationary growth phase. Samples to determine total bacterial abundance and abundance of specific bacterial species were analyzed in 24 to $84 \mathrm{~h}$ intervals. Samples for analysis of bacterial community composition by DGGE were taken at 5 time points in each replicate culture.

Bacterial abundance. Of the formaldehyde-preserved samples (final concentration $4 \%$ ), 1 to $5 \mathrm{ml}$ were filtered onto $0.2 \mu \mathrm{m}$ black polycarbonate MSI filters, stained with acridine orange (Hobbie et al. 1977) and frozen at $-20^{\circ} \mathrm{C}$ until counting. The filters were embedded in paraffin oil and at least 400 cells per filter were counted (or at least 30 fields when cell concentration was low) using an epifluorescence microscope at $1250 \times$ magnification.

DNA extraction and DGGE analysis. DNA extraction and PCR-DGGE analysis were performed as described previously (Langenheder et al. 2003). Briefly, cells from water samples of $500 \mathrm{ml}$ were collected on $0.22 \mu \mathrm{m} \mathrm{GV-filters} \mathrm{(Millipore)} \mathrm{and} \mathrm{lysed} \mathrm{with} \mathrm{lyso-}$ zyme, sodium dodecyl sulphate (SDS) and Proteinase K. DNA was purified from cell debris, protein and humic substances using CTAB (cetyltrimethylammonium bromide) and washed with chloroform/ isoamyl alcohol (24:1). Thereafter, DNA was extracted with phenol/chloroform/isoamylalcohol (25:24:1), precipitated with ice-cold isopropanol and washed with $70 \%$ ethanol. The pellet was dried in a lyophilizer, redissolved in $100 \mu \mathrm{l}$ TE buffer ( $\mathrm{pH}$ 8.0) and incubated with $100 \mu \mathrm{g} \mathrm{ml}^{-1}$ RNAse A for $1 \mathrm{~h}$ at $37^{\circ} \mathrm{C}$.

Fragments (550 bp) of 16S rDNA were amplified using the primers GM5F-GC clamp and DS907R (Teske et al. 1996) under the same PCR conditions as in Langenheder et al. (2003). The program used for amplification consisted of an initial denaturation step at $95^{\circ} \mathrm{C}$ for $5 \mathrm{~min}$, followed by 30 cycles of $30 \mathrm{~s}$ at $95^{\circ} \mathrm{C}, 1 \mathrm{~min}$ annealing at $55^{\circ} \mathrm{C}$ and $1 \mathrm{~min}$ primer extension at $72^{\circ} \mathrm{C}$. The final step was a primer extension for $7 \mathrm{~min}$ at $72^{\circ} \mathrm{C}$.

PCR product of $160 \mathrm{ng}$ was then applied onto polyacrylamide gels $(6.5 \% \mathrm{w} / \mathrm{v})$ with a 25 to $70 \%$ denaturing gradient and run for $6 \mathrm{~h}$ at $200 \mathrm{~V}$ using the Denaturing Gradient Gel Electrophoresis System 2000 (CBS Scientific) (Langenheder et al. 2003). The gel was stained with $10 \mathrm{ml}$ of a 10000 diluted stock solution of SYBR GOLD (Molecular Probes), and analyzed under UV light. The gels were photographed using the gel documentation system 66-1000 (Techtum LAB) including a CCD video camera (Sony) and the image capturer Image-BW Plus (version 4.2). Images were further processed using image-processing software.
Bands were excised from the polyacrylamide gels using sterile surgery blades and re-dissolved in $20 \mu \mathrm{l}$ of sterile water. Five $\mu \mathrm{l}$ were amplified under the conditions described above, but the number of cycles was increased to 35. The PCR products were applied once more onto a DGGE gel together with the original sample, and the band of interest was excised and reamplified as described above, with the exception that we now used the GM5F primer without a GC clamp. The resulting PCR products were applied onto $2 \%$ agarose gel and purified using the QIAquick gel extraction kit (QIAgen). The purified PCR products were cloned using the TOPO TA cloning kit for sequencing (Invitrogen) according to the instructions of the manufacturer. DNA from 5 clones obtained from each band was extracted by heating the cell suspension for $10 \mathrm{~min}$ at $98^{\circ} \mathrm{C}$ and cell debris was removed by centrifugation for $5 \mathrm{~min}$ at $10000 \times g$. The supernatants were used as a template for a PCR amplification of the insert using the external (vector) primers M13f and M13r with PCR conditions as described above.

The PCR products were screened by restriction fragment length polymorphism (RFLP) analysis using simultaneous digestion by Hha I and HaeIII restriction enzymes (Invitrogen) for $16 \mathrm{~h}$ at $37^{\circ} \mathrm{C}$. The fragments were separated on a $2 \%$ agarose gel, stained with ethidium bromide for $15 \mathrm{~min}$ and de-stained with Milli-Q water. All clones with unique RFLP patterns were re-run on a DGGE gel to check if they migrated to the same position as the band in the original sample. Subsequently, all ribotypes were sequenced from both directions using an ABI 3700 DNA sequencer, primers M13f and M13r, and the BigDye terminator kit v. 3.0 (Applied Biosystems). A BLAST search in GenBank (www.ncbi.nlm.nih.gov/BLAST/) was carried out to search for the closest relatives to the sequenced DGGE bands. Sequence alignment and construction of a maximum parsimony tree were done using the ARB software package. Accession numbers of the sequenced DGGE bands are AY337034 to AY337044 (GenBank database release date: August 6, 2003).

Abundance of selected strains in the cultures. The abundance of 7 selected strains was determined by quantitative DNA-DNA hybridization according to Pinhassi et al. (1997). The selection of the strains was based on results from a reverse hybridization experiment (Langenheder et al. 2003), in which we used 68 isolates that had been previously isolated from the Öre Estuary (Kisand et al. 2002). Based on the results, the following strains were selected for this study (GenBank accession numbers given in parentheses): Flavobacterium sp. GOBB3-209 (AF321038), Flavobacterium sp. GOBB3-C101 (AF321008), Pseudomonas putida GOBB3-305 (AF321023), Pseudomonas rhodesia GOBB3-C312 (AF321038), Pseudomonas sp. 
GOBB3-101 (AF321010), Rhodoferax sp. GOBB3-323 (AF321034) and Sphingomonas sp. GOBB3-C201 (AF321036). The 7 strains were chosen because they were abundant members of the bacterial communities in all cultures according to reverse hybridization results. Moreover, they covered a broad phylogenetic range and responded differently with regard to preference for a certain salinity level or source of inoculum (Langenheder et al. 2003). DNA extracted from these strains was then used as a probe against blotted samples from the culture experiment, and quantification of the respective strain was made with the help of standard curves that were hybridized concomitantly with the samples against the same probe.

The bacteria from $10 \mathrm{ml}$ of sample were collected on $0.45 \mu \mathrm{m}$ hybridization membranes (Hybond-N+, Amersham) using a blotting apparatus (GIBCO BRL with $6 \mathrm{~mm}$ diameter dots) and a lid containing 24 wells, and the cells were lysed following the same procedure as described by Langenheder et al. (2003). Standard series for each of the strains, which we used as probes against the DNA obtained from the culture experiment, were prepared as described elsewhere (Kisand et al. 2002) and blotted and lysed as described by Langenheder et al. (2003). For each strain, duplicate or triplicate dilution series were prepared, because we found that the signal depended on the growth state of the cells. Dilutions ranged from $1 \times$ $10^{4}$ to $7 \times 10^{6}$ cells per dot. Using replicate dilution series of studied strains, the detection limit was estimated to be $20 \times 10^{3}$ cells ml ${ }^{-1}$ in this study. For strain Sphingomonas sp. GOBB3-C201, however, the detection limit was $40 \times 10^{3}$ cells ml $^{-1}$ due to higher variability between replicate dilution series. All samples and standard series determined for hybridization using the same strain a probe were transferred into the same hybridization tube and hybridized together, even though they were blotted onto different membranes.

For probe preparation, chromosomal DNA of an isolate, from which the DNA was extracted as described above, was labelled with $50 \mu \mathrm{Ci}$ of $\left[\alpha-{ }^{32} \mathrm{P}\right]$ dATP (3000 Ci mM ${ }^{-1}$, Amersham Pharmacia Biotech) using the High Prime DNA Labelling Kit (Roche Diagnostics) as described earlier. The hybridization procedure was identical to the one described in a previous study (Langenheder et al. 2003).

The radioactive signal was transferred into cell number with the help of standard curves obtained from the dilution series from the respective strain used as a probe. Comparison of the radioactive labelling with that of the standard series allowed us to calculate the cell concentration of an unknown sample. Abundances were determined by taking the mean values from all standard dilutions.
The amount of cross-hybridization was estimated exemplarily for 2 different pairs of isolates from the Öre Estuary belonging to the genus Pseudomonas according to Kisand et al. (2002): Pseudomonas sp. GOBB3106 (accession number AF321011) and Pseudomonas sp. GOBB3-101 (accession number AF321010), showed $96 \% 16$ S rDNA similarity and 55\% genomic DNA similarity giving an approximately $5 \%$ overestimation of the total abundance due to cross-hybridization with the respective other strain. For Pseudomonas sp. GOBB3-103 (AF321030) and Pseudomonas sp. GOBB3-303, cross-hybridization was much lower since these 2 strains had $99 \%$ 16S rDNA sequence similarity but only $4.4 \%$ genomic DNA similarity. Generally, cross-hybridization values of approximately $10 \%$ are likely in complex communities where several highly related species co-occur (e.g. Kisand et al. 2002), but are expected to be lower in culture systems that have a relatively low genome complexity such as batch cultures (Greene \& Voordouw 2003). We are aware that the DNA probes used in this study do not allow the specific detection of only the target strain, but also detect an undefined number of closely related strains that contribute to the overall hybridization signal since they bind to the DNA of the target strain. In the present study, we use the word 'strain' because it is convenient, but we always mean the target strain plus an undefined number of closely related strains.

Net specific growth rates $(\mu)$ for the time interval between 84 and $180 \mathrm{~h}$ after the start of the experiment were calculated according to $\mu=\ln N_{2}-\ln N_{1} / \Delta t$, where $N$ is bacterial abundance and $t$ is time. This was done for each of the 7 strains as well as for total bacterial numbers.

Statistical analysis. A 3-way factorial ANOVA was applied to test whether salinity, source of inoculum and strain identity significantly affected net specific growth rates. A 3-way repeated measures ANOVA on logtransformed values for strain abundances was performed for the same interval used to calculate the net specific growth rates (84 to $180 \mathrm{~h}$ ). While the ANOVA on net specific growth rates gave us information on how salinity, source of inoculum, and strain identity affect the net rate of biomass accumulation during the complete time interval, the repeated measures ANOVA (using changes in cell number over time as a dependent variable) provided more detailed information concerning the growth dynamics during this period. All data were checked for homogeneity of variances.

\section{RESULTS AND DISCUSSION}

We studied the growth dynamics and potential succession of riverine and estuarine bacteria at freshwater and estuarine salinities in batch cultures based on 
Fig. 1. Development of total bacterial abundance and band number on DGGE gels at different growth stages of the batch culture experiments. Values for bacterial abundance are shown on a logarithmic scale and each point represents mean values $\pm \mathrm{SD}(\mathrm{N}=3)$. The first sample for DGGE analysis was taken $60 \mathrm{~h}$ (RIV $0 \%$ : riverine bacteria at $0 \%$ ), $84 \mathrm{~h}$ (RIV $4 \%$ : riverine bacteria at $4 \%$ ) and $108 \mathrm{~h}$ (EST $0 \%$, EST $4 \%$ : estuarine bacteria at 0 and $4 \%$, respectively) after inoculation. For 3 time points, DGGE profiles from all replicate cultures were analyzed. Mean number of bands \pm SD are given. Absence of error bars indicates identical profiles among replicate cultures. Vertical dashed lines indicate the time interval between 84 and $180 \mathrm{~h}$ for which growth dynamics in the cultures were analyzed by DNA-DNA hybridization (see 'Materials and methods' for more detailed information)
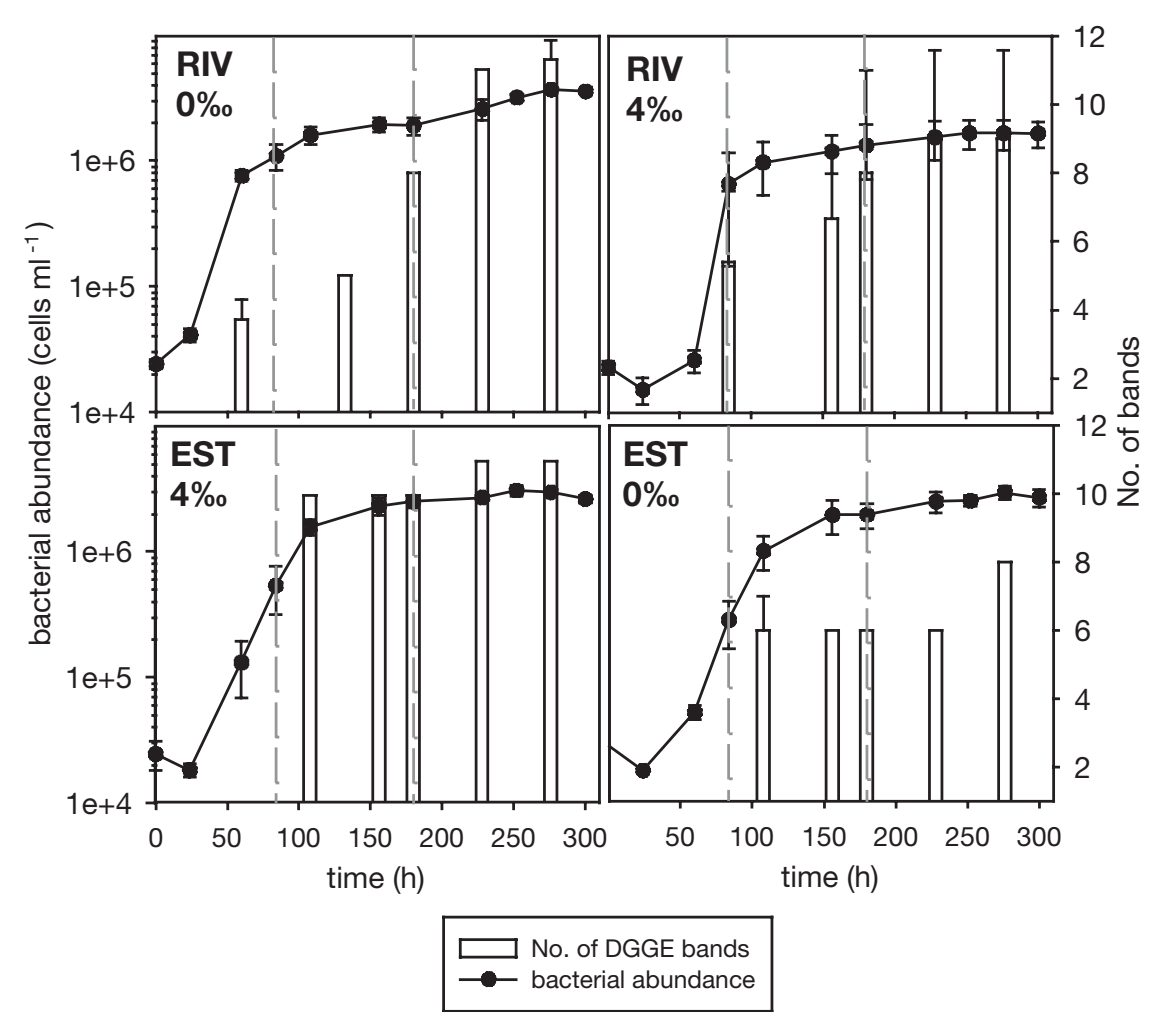

DOM from a river, and bacterial inocula from the river and its estuary. Our main purpose was to compare bacterial communities of riverine versus estuarine origin growing on riverine DOM at different salinities, and to address the effect of salinity and the source of the inoculum on community composition and functioning (Langenheder et al. 2003) and growth dynamics within the bacterial communities (this study). Riverine DOM, which is dominated by allochthonous humic substances (Ivarsson \& Jansson 1994), comprises a major fraction of the estuarine DOM (Zweifel et al. 1995, Wikner \& Hagström 1999, Sandberg et al. 2004). Thereby, riverine DOM is part of the substrate pool available not only to the riverine but also to the estuarine bacteria.

In general, bacterial community growth (Fig. 1) showed a lag phase, a logarithmic growth phase, and a 2-phasic stationary phase. The latter consisted of an initial phase of growth deceleration, where growth slows down due to decreasing substrate availability, and the maximum ('true') stationary phase, a prolonged period of starvation with no net growth or even negative growth (Wanner \& Egli 1990, Mason \& Egli 1993). Based on these growth patterns, our more detailed analysis of temporal community dynamics by DNA-DNA hybridization and DGGE covered late exponential and growth deceleration phases as shown in Fig. 1.

\section{Denaturing gradient gel electrophoresis}

The banding patterns of DGGE were highly reproducible and showed similarities $>82 \%$ between replicates during all growth stages (Langenheder et al. 2003). The number of bands increased over time in all cultures (Fig. 1), since some new bands appeared in the stationary growth phase. Bands that were present already during the exponential growth phase remained until the end of the stationary growth phase (shown for RIV $0 \%$ and EST $4 \%$ in Fig. 2). The increase in number of bands detectable on the DGGE gels was most apparent in cultures that received a riverine inoculum. In contrast, in cultures receiving an estuarine inoculum, only a few bands were added during the stationary growth phase. (Figs. $1 \& 2$ ).

The persistence throughout the experiment of bands that occurred early in the cultures is not surprising. In a batch culture there should ideally be no loss of cells. Hence, a succession in such cultures should primarily result in the accumulation of the total number of bands in response to additional populations reaching the detection level of DGGE. However, some loss mainly due to viral lysis is conceivable.

In closed systems like batch cultures, all species that responded by growth must have been present in the original inoculum, but they were growing to levels that could be detectable by DGGE at different times. As a 


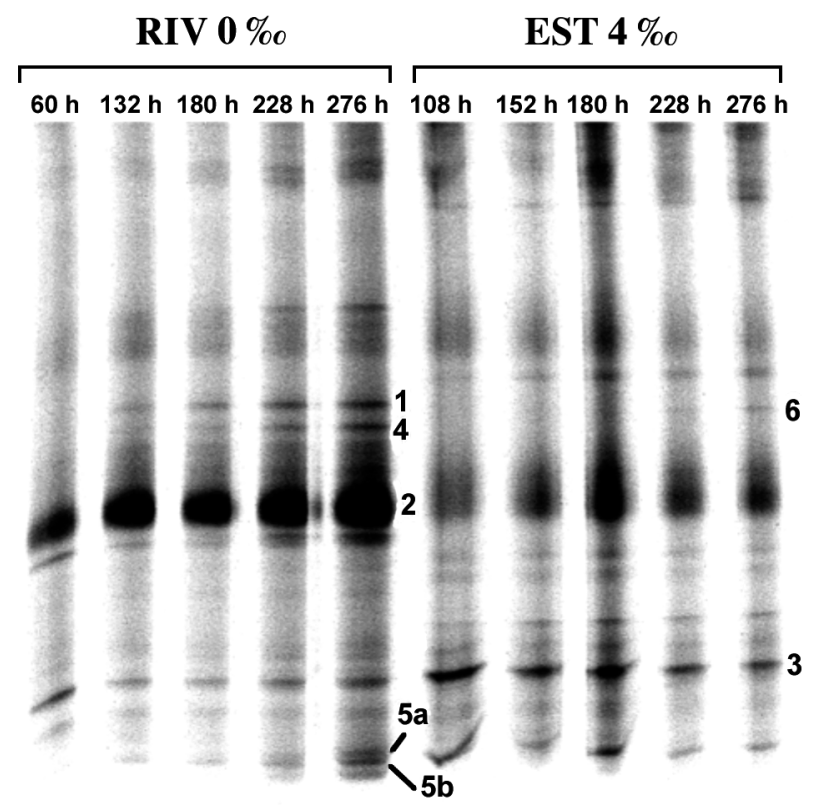

Fig. 2. DGGE profiles obtained from samples from different growth stages of the batch culture experiment in RIV $0 \%$ and EST $4 \%$. Bands that were excised and sequenced are indicated by numbers (1 to 6 ) to the right of the respective band. Bands were excised only from samples from the final stage $(276 \mathrm{~h})$

rule of thumb, it is assumed that only taxa comprising $>1 \%$ of the total bacterial DNA become detectable on DGGE gels (Muyzer et al. 1993). The appearance of specific bands in stationary growth phase may therefore reflect slow-growing species that did not previously reach detectable quantities (i.e. detectable fractions of the total bacterial DNA). Alternatively, these bands represented a succession, caused by complex interactions such as growth on secondary compounds excreted by other bacteria. Competitive advantage of strains with higher affinity for certain organic substrates could also contribute to a successional pattern, when strains with lower affinity but higher growth capacity have suppressed the substrate concentration.

Previous results showing that aquatic bacterial communities can differ in growth characteristics support these assumptions. Weinbauer \& Höfle (1998) studied life strategies in 2 species of lake water bacteria and classified the strain Aeromonas hydrophila PU7718 as a fast-growing and metabolically versatile r-strategist and Comamonas acidovornas PX54 as a slow-growing k-strategist specialized on low-quality substrates. Similarly, Pernthaler et al. (2001) demonstrated clearly different growth patterns in 2 different marine strains, Pseudoalteromonas sp. and Oceanospirillum sp., grown together in batch cultures. Recently, Pinhassi \& Berman (2003) suggested that growth pattern and life strategy differ among subgroups of the Proteobacteria.
Thus, $\gamma$-Proteobacteria seemed to be fast-growing opportunists dominating at high nutrient levels, whereas they were out-competed by $\alpha$-Proteobacteria at low nutrient concentrations.

So far, only a few studies have addressed the question of bacterial succession within batch cultures. In cultures with water and inocula from a clearwater lake, Höfle (1988) observed a replacement of different abundant species using 5S rRNA analysis, while no pronounced changes in the relative abundance of genera occurred throughout the different batch culture growth stages in humic water cultures. In cultures enriched with mucopolysaccharide, Janse et al. (2000) found that after mucopolysaccharide degradation ceased almost completely there was a clear increase in band diversity without loss of bands that were already abundant at earlier stages. In contrast, there was no change in the composition or intensity of DGGE bands during the time period in which most of the substrate was degraded (Janse et al. 2000). Thus, there are reported observations suggesting a succession of bacteria in response to changing substrate conditions.

Six bands representing different patterns of occurrence on the DGGE gels were excised, cloned and sequenced (Fig. 2). We restricted the sequence analysis of selected DGGE bands to RIV $0 \%$ and EST $4 \%$, because they resembled naturally occurring combinations of inoculum and salinity (riverine bacteria growing at $0 \%$, estuarine bacteria growing at $4 \%$ o). RFLP analysis of the cloned partial 16S rDNA fragments showed that single bands often contained DNA from more that one sequence as identified by unique RFLP patterns. In 5 cases, a single band contained 2, and in 1 case 3 different sequences. The 2 sequences obtained from Band 5 (Fig. 2; 5a and 5b) traveled to a slightly different position when re-run on a DGGE gel, corresponding to 2 bands close together on the DGGE gel from the original batch culture samples (Fig. 2). Hence, in this case it seems likely that DNA from both bands was contained in the gel slice that was excised from the gel and subsequently cloned and sequenced. In all other cases, however, the DNA from the sequences with different RFLP patterns traveled to indistinguishable positions on the DGGE gel. Often these sequences were identical (Fig. 3, Bands 2a,b and $4 \mathrm{a}, \mathrm{b} ; 100 \%$ similarity) or very closely related (Fig. 3, Band $3 \mathrm{a}, \mathrm{b}, \mathrm{c}_{\mathrm{i}}>97 \%$ similarity). In 2 cases (Bands $1 \mathrm{a}, \mathrm{b}$ and $6 a, b)$, however, the 2 respective sequences were clearly different (Fig. 3), even if they still belonged to the same cluster within the Bacteroidetes. Generally, our results confirm earlier observations that a single band can contain more than one sequence (Sekiguchi et al. 2001, Casamayor et al. 2002a, Crump et al. 2003). In the extensive study by Crump et al. (2003), only $13 \%$ of the bands contained 2 or more different se- 


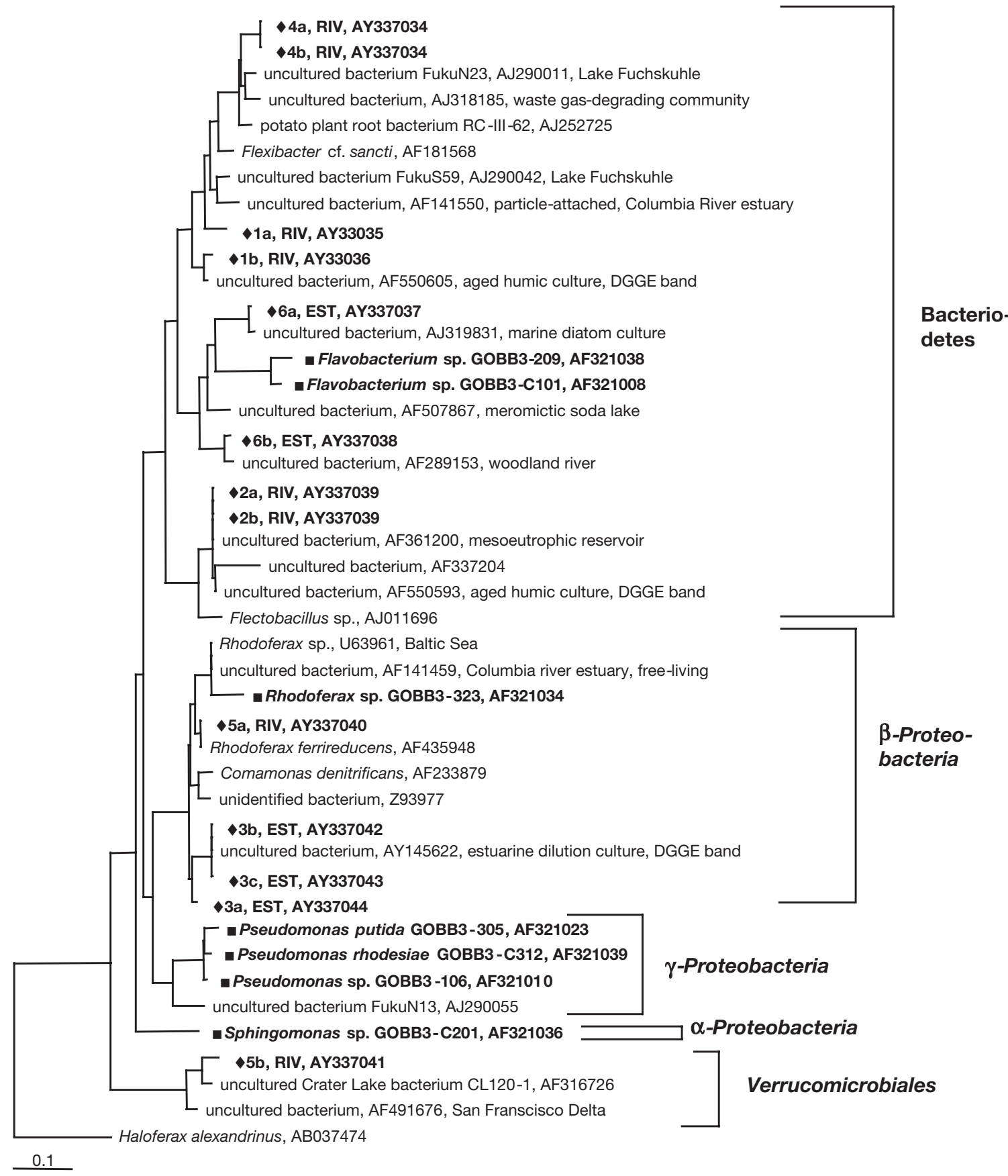

Fig. 3. Maximum parsimony tree showing the phylogenetic position of the sequenced DGGE bands and of 7 selected strains that were followed by quantitative DNA-DNA hybridization. All taxa included in this study are printed bold; $(\diamond)$ DGGE bands and (ם) selected strains are shown. Numbers 1 to 6 refer to bands that were cut-out from the DGGE gel; letters a to c refer to the different ribotypes obtained from 5 randomly chosen clones from the same band as identified by RFLP analysis

quences, whereas we found $40 \%$ of all bands to consist of mixed sequences. In our study, however, we used a longer fragment (550 bp) and a steeper gradient (25 to $70 \%$ ) than Crump et al. (2003) ( 200 bp and 30 to $50 \%$, respectively). Thus, our DGGE analysis might have had a lower resolution than the one by Crump et al.
(2003), which potentially explains why we observed a higher percentage of 'multiple sequence bands'.

Bands that were excised from the treatments receiving a riverine inoculum were generally related to freshwater bacteria (Fig. 3), whereas those from cultures receiving an estuarine inoculum were related 


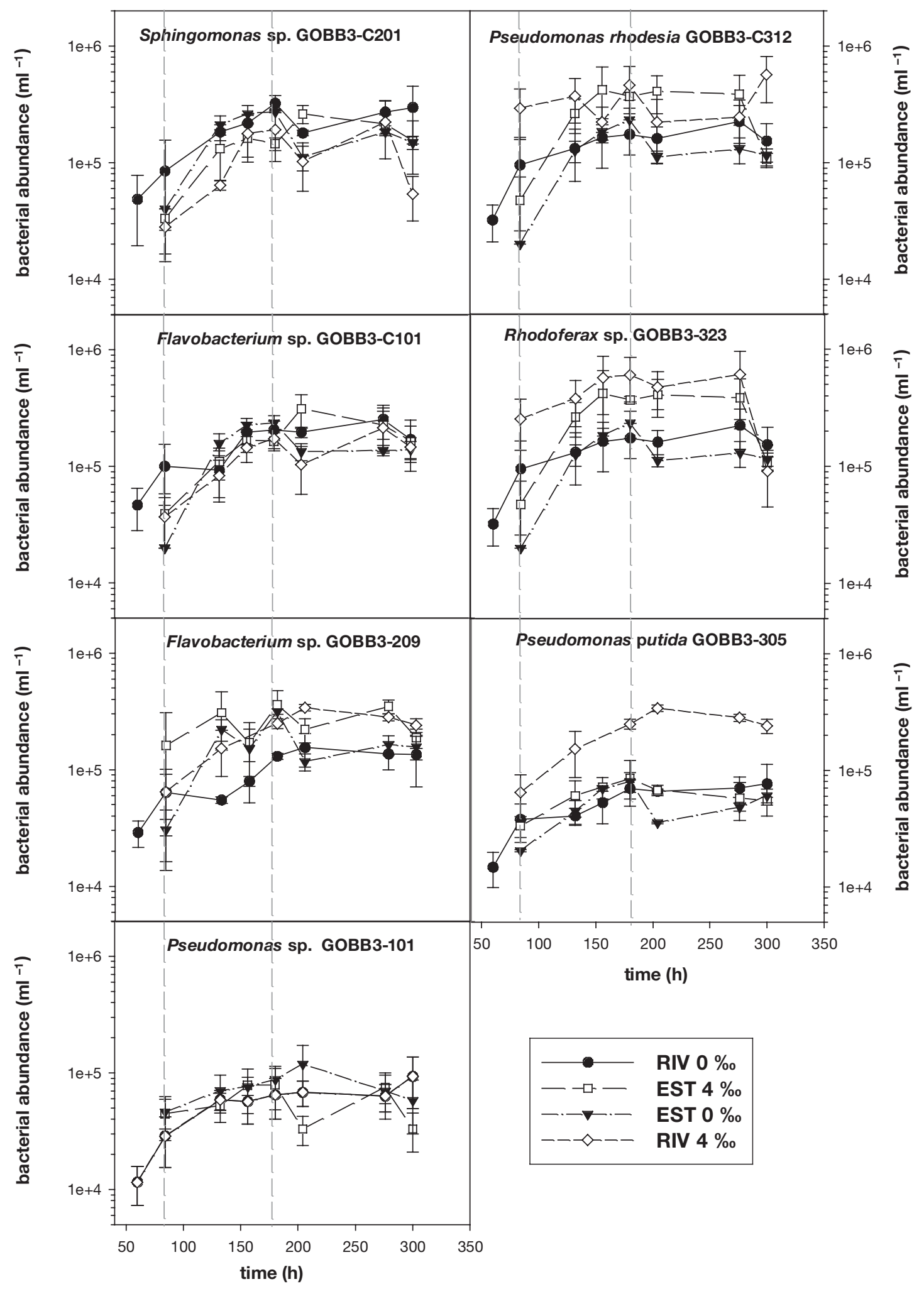

Fig. 4. Temporal development of 7 selected strains in the batch cultures experiment as determined by DNA-DNA hybridization. Indicated cell numbers for each of the strains are composite numbers including the target strain itself but also an unknown number of close relatives. Each value represents mean value $\pm \mathrm{SE}(\mathrm{N}=3)$. Vertical dashed lines indicate the time interval between 84 and $180 \mathrm{~h}$ for which growth dynamics in the cultures were analyzed (see 'Materials and methods' for more detailed information) 
to sequences from marine or estuarine environments or cultures (Schäfer et al. 2002, Selje \& Simon 2003). Four of the 6 bands retrieved from the gel were most closely related to different groups within the Bacteroidetes. These bacteria are known to play an important role in the degradation of complex polymers in aquatic environments (Kirchman 2002) and have previously been suggested as important consumers of riverine DOC in the northern Baltic Sea (Kisand et al. 2002). Our results support the fact that bacteria in the Bacteroidetes group are especially adapted to catabolize substrates in the riverine DOM. Many sequences obtained were closely related to bacteria from environments with high organic carbon input of terrestrial origin (e.g. Bands $1 \mathrm{~b}$, $4 \mathrm{a}, \mathrm{b}$, and $6 \mathrm{~b}$, Fig. 3). Band $5 \mathrm{~b}$ was closest related to sequences within the Verrucomicrobiales CL 12010 cluster (Urbach et al. 2001, Zwart et al. 2002). Members of this cluster have been found in a crater lake with little input of allochthonous material (Urbach et al. 2001), but also in a moderately humic lake where they appeared to be favored by a high availability of phosphorus (Lindström et al. 2004). Band 5a was most closely related to Rhodoferax ferrireducens (Finneran et al. 2003), a facultative anaerobe that oxidizes acetate with the reduction of Fe(III). To summarize, several of the sequenced bands resembled sequences from other environments influenced by allochthonous carbon.

Even though the number of bands sequenced in this study is very limited, the results indicate that any potential succession in the cultures took place within the Bacteroidetes, $\beta$-Proteobacteria and Verrucomicrobiales groups, rather than as a shift between major phylogenetic groups. This suggests that functional affiliation occurs on a lower taxonomic level than the phylum level. Four of the sequenced bands (Band 1, Bacteroidetes; Band 2, Bacteroidetes; Band 3, $\beta$-Proteobacterium; and Band 5b, Verrucomicrobiales) were already detectable during early stages of the growth phase, whereas Band 4, Bacteroidetes; Band 5a, Rhodoferax ferrireducens; and Band 6, Bacteroidetes did not appear until the late stationary growth phase (Fig. 2).

\section{Quantitative DNA-DNA hybridization}

The selected bacteria, which were isolated from the estuary, grew to appreciable numbers in all treatments (Fig. 4), but the maximum attained abundance differed more than 2-fold between different strains and treatments (Table 1, STRAIN, p < 0.001; Fig. 4).

At the start of the experiment, the inoculum was 1:30 diluted with sterile river water, and none of the target strains for DNA-DNA hybridization reached above the detection limit of the method (approx. $20 \times 10^{3}$ cells $\mathrm{ml}^{-1}$ ). Since we were not able to monitor these strains during early exponential growth, we applied net specific growth rates to the time from detection until the start of the stationary growth phase (84 to $180 \mathrm{~h}$; Fig. 4). Net growth rates of strains monitored by DNADNA hybridization were generally higher in cultures that received an estuarine inoculum in comparison to those receiving a riverine inoculum, independent of strain identity and salinity level (Table 2). However, we found a strong significant effect of strain identity on the dynamics in cell abundance (Table 1). This indicates that the strains differed in temporal dynamics on a shorter time scale, i.e. showed varying patterns of net increase during sub-periods of the total observed time period.

Salinity affected the total cell yield reached by some strains (Table $1, \mathrm{SAL} \times \mathrm{STRAIN}, \mathrm{p}=0.028$ ). Pseudomonas rhodesia GOBB3-C312 and Rhodoferax sp. GOBB3-323 had higher realized carrying capacities at $4 \%$ (Fig. 4, p-values in Tukey Honestly Significant Difference [HSD] post-hoc test: $p=0.039$ and 0.008,

Table 1. p-values of a 3-way repeated measures ANOVA performed on strain abundances as determined by DNA-DNA hybridization during 4 time points between 84 and $180 \mathrm{~h}$ (TIME). Grouping factors were SAL (salinity level in the culture), INOC (source of inoculum) and STRAIN (strain \#ID). Three- and 4-factor interactions are not shown ( $p>0.05$ in all cases). ${ }^{*} \mathrm{p}<0.05$

\begin{tabular}{|lc|}
\hline Effect & p-value \\
\hline INOC & 0.878 \\
SAL & 0.086 \\
STRAIN & $0.000^{*}$ \\
INOC $\times$ SAL & 0.522 \\
INOC $\times$ STRAIN & 0.763 \\
SAL $\times$ STRAIN & $0.028^{*}$ \\
TIME & $0.000^{*}$ \\
TIME $\times$ INOC & $0.000^{*}$ \\
TIME $\times$ SAL & 0.331 \\
TIME $\times$ STRAIN & $0.000^{*}$ \\
\hline
\end{tabular}

Table 2. p-values of a 3-way factorial ANOVA performed on net specific growth rates of 7 selected strains as determined by DNA-DNA hybridization. Grouping factors were SAL (salinity level in the culture), INOC (source of inoculum) and STRAIN (strain \#ID). ${ }^{*} \mathrm{p}<0.05$

\begin{tabular}{|lc|}
\hline Effect & p-value \\
\hline SAL & 0.137 \\
INOC & $0.001^{*}$ \\
STRAIN & 0.053 \\
SAL $\times$ INOC & 0.079 \\
SAL $\times$ STRAIN & 0.763 \\
INOC $\times$ STRAIN & 0.341 \\
SAL $\times$ INOC $\times$ STRAIN & 0.933 \\
\hline
\end{tabular}


respectively), whereas Sphingomonas sp. GOBB3C201 showed a non-significant $(\mathrm{p}=0.077)$ preference for $0 \%$. The temporal dynamics of strains, in contrast, were not affected by salinity in all cases (SAL $\times$ TIME $\times$ STRAIN, $p=0.62$ ). This indicated that the enhancement of bioavailable substrate by salinity as previously found (Stepanauskas et al. 1999, Wikner et al. 1999) was most likely a species-specific response.

In summary, our results show that the source of the inoculum (riverine vs. estuarine), was a stronger regulating factor for temporal dynamics within the studied bacterial communities than salinity. In contrast, only salinity but not the origin of the inoculum had an effect on the overall cell yields reached by some of the strains. This indicates that changes in environmental conditions (such as salinity) might operate on a general level and regulate the biomass accumulation of different bacteria, whereas growth dynamics could be mainly regulated by interactions between bacterial community members (e.g. competition).

The temporal dynamics of the 7 selected strains did not show a clear successional pattern, and affiliation of species to, e.g., a fast-growing opportunistic type (' $r$ strategist') or a slow-growing type ('K-strategist') was not feasible. All investigated strains showed similar patterns of net increase during the investigated time period, although small-scale difference in growth occurred. We are aware that these relatively moderate temporal dynamics might be a consequence of crosshybridization (discussed below), since the hybridization signal is not strain specific but envelopes some other closely related strains as well. This might dampen temporal dynamics and give a wrong impression of uniformity if such dynamics primarily occur within these groups of organisms. Moreover, we investigated only 7 strains, which were selected based on a screening of 68 isolates by reverse DNA-DNA hybridization and were all among the abundant members of the bacterial community in the cultures (Langenheder et al. 2003). We cannot exclude that all 7 strains per se resemble the same growth type, i.e. the opportunistic type that could be favored by growth conditions in batch cultures.

The substantial growth of estuarine bacteria on DOM sampled in the adjacent river supports the fact that terrestrial organic matter is a significant bacterial substrate in the estuary ( Wikner et al. 1999, Sandberg et al. 2004). Thus, we can assume that estuarine bacteria rely at least partly on riverine DOM to fulfill their energy demands. Transferred to a more natural scenario, we might even speculate that the ability of the 7 selected strains to use riverine DOM under both freshwater and brackish conditions might indicate that they are riverine strains that are imported along with riverine DOM to the estuary. The importance of such bacterial transport between systems has recently been pointed out (Crump et al. 2004, Lindström \& Bergström 2004).

The strains reached maximal abundances of up to $0.5 \times 10^{6}$ cells ml ${ }^{-1}$ after roughly $180 \mathrm{~h}$, and all 7 strains together accounted for a significant fraction of the respective total bacterial cell numbers in the cultures (25 to $135 \%$ ). These values show firstly that culturable species can account for a marked fraction of bacterial total counts (Rehnstam et al. 1993, Pinhassi et al. 1997, Kisand et al. 2002). However, there is a risk of overestimation of species abundance due to cross-hybridization to related bacteria and multiple chromosome copies per cell. The high fraction of the total community that was covered by the 7 strains indicates that cross-hybridization was a problem in our study. Natural microbial communities often exhibit a high genetic microheterogeneity with numerous closely related but distinct phylotypes (e.g. García-Martínez \& Rodríguez-Valera 2000, Casamayor et al. 2002b, Ferris et al. 2003), which cannot be distinguished with the DNA-DNA hybridization method. Cross-hybridization, however, is seldom found to be a major problem between community members that have 16S rRNA similarities below $95 \%$ (Kisand et al. 2002); therefore, we expected the risk of overlap between the hybridization signal obtained from the 7 different DNA probes used in this study to be relatively low (see 'Materials and methods'). Thus, the observed effects of salinity and the source of the inoculum were mostly unaffected by cross-hybridization. In contrast, each 'signal' does not specifically detect the target strain only, but also covers a group of close relatives of unknown number and identity.

The between-replicate variability of abundance derived from DNA-DNA hybridization was high (average coefficient of variance for 7 strains, both cultures and all sampling points: $\mathrm{CV}=59 \pm 38 ; \mathrm{N}=236$ ). In previous studies, a similar hybridization technique exhibited similar variability (Gonzaléz et al. 1999), but it has also been successfully applied to natural aquatic bacterial communities with less variability (Pinhassi et al. 1997, Kisand et al. 2002). Possibly, random processes ('founder effects') contributed to the high variability, due to low cell numbers in the inocula.

\section{Comparison of DNA-DNA hybridization and DGGE}

Hybridization of the 7 selected strains and DGGE analysis yielded different results regarding the temporal development of the composition of the communities. First, the DNA-DNA hybridization showed that, despite differences in salinity and source of inoculum, the 7 selected strains and their close relatives were abundant 
and probably also dominant members of the bacterial communities in all cultures. DGGE analysis, in contrast, demonstrated that the community similarity among treatments was low (Langenheder et al. 2003). In addition, no band sequenced from the DGGE gel matched the strains that were followed by DNA-DNA hybridization (Fig. 3), something that would be intuitively expected assuming that DGGE detects dominant members of bacterial communities (Torsvik et al. 1998). Cross-hybridization, which results in a certain inaccuracy of the DNA probe results, includes the possibility that some of the DGGE bands represent populations that contributed to the hybridization signals, especially in cases where strains and DGGE bands clustered closely together (Fig. 3). However, for our study, this scenario was unlikely since 16S rDNA similarities between the probes used for DNA-DNA hybridization and the DGGE sequences were below $92 \%$ in all cases. As mentioned above, it has been shown before that cross-hybridization is only a minor problem when 16S rDNA similarities are that low (Kisand et al. 2002). The discrepancy between DNA-DNA hybridization and DGGE might have been a consequence of the low number of DGGE bands sequenced, overestimation of abundances by quantitative DNA-DNA hybridization, or PCR-related biases of the DGGE-analysis (von Wintzingerode et al. 1997, Polz \& Cavanaugh 1998), thus questioning the assumption that DGGE detects dominant bacterial community members. Recently, Kisand \& Wikner (2003) compared quantitative DNA-DNA hybridization with isolated strains and DGGE on samples from the Öre Estuary and found that the 2 methods do not detect the same organisms on the species level. However, even if the 2 independent methods detected different taxa on lower taxonomic levels, our results generally confirm earlier findings that members of the Bacteroidetes and the $\beta$-Proteobacteria, especially of the genus Rhodoferax, are abundant members of communities in systems where growth is to a large extent supported by riverine DOM (Kisand et al. 2002, Kisand \& Wikner 2003).

According to the results from the DNA-DNA hybridization, there is no reason to conclude that the appearance of specific bands on DGGE gels during stationary growth phase reflect a true successional pattern. More likely the 'newly appearing taxa' represent slow-growing bacteria that did not previously reach the detection threshold, i.e. a significant fraction of the total bacterial DNA.

In conclusion, the remarkably similar development, dynamics and yield of the strains investigated by DNADNA hybridization suggest that exposure to changes in salinity was not a major regulator of community dynamics. Hence, it is possible that bacteria degrading riverine DOM under brackish conditions are immi- grants that enter the estuarine environment along with the riverine DOM. DGGE analysis, however, indicated that there might be a differentiation of bacterial populations into slow- and fast-growing types, potentially related to changes in the labile DOM pool.

Acknowledgements. We thank Nina Andersson for help during the set up of the experiment and the staff at Umeå Marine Sciences Centre for their kind help with the field sampling. We are very grateful to Alexander Eiler and Stefan Bertilsson for their help with the cloning and sequencing. This work was supported by grants from the Foundation for Strategic Environmental Research, the Swedish Research Council and the Malméns foundation.

\section{LITERATURE CITED}

Bishop K, Pettersson C (1996) Organic carbon in the boreal spring flood from adjacent subcatchments. Environ Int 22: $535-540$

Casamayor EO, Massana R, Benlloch S, Ovreas L and 6 others (2002a) Changes in archaeal, bacterial and eukaryal assemblages along a salinity gradient by comparison of genetic fingerprinting methods in a multipond solar saltern. Environ Microbiol 4:338-348

Casamayor EO, Pedrós-Alió C, Muyzer G, Amann R (2002b) Microheterogeneity in $16 \mathrm{~S}$ ribosomal DNA-defined bacterial populations from a stratified planktonic environment is related to temporal changes and to ecological adaptations. Appl Environ Microbiol 68:1706-1714

Cottrell MT, Kirchman DL (2000) Natural assemblages of marine proteobacteria and members of the CytophagaFlavobacter cluster consuming low- and high- molecular weight dissolved organic matter. Appl Environ Microbiol 66:1692-1697

Covert JS, Moran MA (2001) Molecular characterization of estuarine bacterial communities that use high- and lowmolecular weight fractions of dissolved organic carbon. Aquat Microb Ecol 25:127-139

Crump BC, Kling GW, Bahr M, Hobbie JE (2003) Bacterioplankton community shifts in an artic lake correlate with seasonal changes in organic matter sources. Appl Environ Microbiol 69:2253-2268

Crump BC, Hopkinson CS, Sogin ML, Hobbie JE (2004) Microbial biogeography along an estuarine salinity gradient: combined influences of bacterial growth and residence time. Appl Environ Microbiol 70:1494-1505

Eiler A, Langenheder S, Bertilsson S, Tranvik LJ (2003) Heterotrophic bacterial growth efficiency and community structure at different natural organic carbon concentrations. Appl Environ Microbiol 69:3701-3709

Ferris MJ, Kühl M, Wieland A, Ward DM (2003) Cyanobacterial ecotypes in different optical microenvironments of a $68^{\circ} \mathrm{C}$ hot spring mat community revealed by $16 \mathrm{~S}-23 \mathrm{~S}$ rRNA internal transcribed spacer region variation. Appl Environ Microbiol 69:2893-2898

Finneran KT, Johnsen CV, Lovley DR (2003) Rhodoferax ferrireducens sp. nov., a psychrotolerant, facultatively anaerobic bacterium that oxidizes acetate with the reduction of Fe(III). Int J Syst Evol Microbiol 53:669-673

García-Martínez J, Rodríguez-Valera F (2000) Microdiversity of uncultured marine prokaryotes: the SAR11 cluster and the marine Archaea of Group I. Mol Ecol 9:935-948

Gonzaléz JM, Hodson RE, Moran MA (1999) Bacterial populations in replicate marine enrichment cultures: assessing 
variability in abundance using 16S rRNA-based probes. Hydrobiologia 401:69-75

Greene J, Voordouw G (2003) Analysis of environmental communities by reverse sample genome probing. J Microbiol Methods 53:211-219

Hobbie JE, Daley RJ, Jasper S (1977) Use of nucleopore filters for counting bacteria by fluorescence microscopy. Appl Environ Microbiol 33:1225-1228

Höfle M (1988) Taxonomic structure of bacterial communities in mixed cultures as measured by low molecular weight RNA profiles. Arch Hydrobiol Beih Ergebn Limnol 31:71-77

Ivarsson H, Jansson M (1994) Temporal variations of organic carbon in River Öre, Northern Sweden. Verh Int Verein Limnol 25:1522-1525

Janse I, Zwart G, van der Maarel M, Gottschal JC (2000) Composition of the bacterial community degrading Phaeocystis mucopolysaccharides in enrichment cultures. Aquat Microb Ecol 22:119-133

Kirchman DL (2002) The ecology of Cytophaga-Flavobacteria in aquatic environments. FEMS Microbiol Ecol 39:91-100

Kisand V, Wikner J (2003) Combining culture-dependent and -independent methodologies for estimation of richness of estuarine bacterioplankton consuming riverine dissolved organic matter. Appl Environ Microbiol 69:3607-3616

Kisand V, Cuadros R, Wikner J (2002) Phylogeny of culturable estuarine bacteria catabolizing riverine organic matter in the northern Baltic Sea. Appl Environ Microbiol 68:379-388

Langenheder S, Kisand V, Wikner J, Tranvik LJ (2003) Salinity as a structuring factor for the composition and performance of bacterioplankton degrading riverine DOC. FEMS Microbiol Ecol 45:189-202

Lindström ES, Bergström AK (2004) Influence of inlet bacteria on bacterioplankton assemblage composition in lakes of different hydraulic retention time. Limnol Oceanogr 49:125-136

Lindström ES, Vrede K, Leskinen E (2004) Response of a member of the Verrucomicrobia, among the dominating bacteria in a hypolimnion, to increased phosphorus availability. J Plankton Res 26:241-246

Mason CA, Egli T (1993) Dynamics of microbial growth in the decelerating and stationary phase of batch culture. In: Kjelleberg S (ed) Starvation in Bacteria. Plenum Press, New York, p 81-101

Muyzer G, Dewaal EC, Uitterlinden AG (1993) Profiling of complex microbial populations by denaturing gradient gel-electrophoresis analysis of polymerase chain reaction amplified genes coding for 16s ribosomal-RNA. Appl Environ Microbiol 59:695-700

Pernthaler A, Pernthaler J, Eilers H, Amann R (2001) Growth patterns of two marine isolates: adaptations to substrate patchiness? Appl Environ Microbiol 67:4077-4083

Pettersson C, Allard B, Boren H (1997) River discharge of humic substances and humic-bound metals to the Gulf of Bothnia. Estuar Coast Shelf Sci 44:533-541

Pinhassi J, Berman T (2003) Differential growth response of colony-forming alpha- and gamma-Proteobacteria in dilution culture and nutrient addition experiments from Lake Kinneret (Israel), the Eastern Mediterranean Sea, and the Gulf of Eilat. Appl Environ Microbiol 69:199-211

Pinhassi J, Zweifel UL, Hagström Å (1997) Dominant marine bacterioplankton species found among colony-forming bacteria. Appl Environ Microbiol 63:3359-3366

Polz MF, Cavanaugh CM (1998) Bias in template to product ratios in multitemplate PCR. Appl Environ Microbiol 64: 3724-3730

Rehnstam AS, Backman S, Smith DC, Azam F, Hagström A (1993) Blooms of sequence-specific culturable bacteria in the sea. FEMS Microbiol Ecol 102:161-166
Sandberg J, Andersson A, Johansson S, Wikner J (2004) Pelagic food web structure and carbon budget in the northern Baltic Sea: potential importance of terrigenous carbon. Mar Ecol Prog Ser 268:13-29

Schäfer H, Abbas B, Witte H, Muyzer G (2002) Genetic diversity of 'satellite' bacteria present in cultures of marine diatoms. FEMS Microbiol Ecol 42:25-35

Sekiguchi H, Tomioka N, Nakahara T, Uchiyama H (2001) A single band does not always represent single bacterial strains in denaturing gradient gel electrophoresis analysis. Biotechnol Lett 23:1205-1208

Selje N, Simon M (2003) Composition and dynamics of particle-associated and free-living bacterial communities in the Weser estuary, Germany. Aquat Microb Ecol 30: 221-237

Sondergaard M, Middelboe M (1995) A cross-system analysis of labile dissolved organic carbon. Mar Ecol Prog Ser 118: 283-294

Stepanauskas R, Edling H, Tranvik LJ (1999) Differential dissolved organic nitrogen availability and bacterial aminopeptidase activity in limnic and marine waters. Microb Ecol 38:264-272

Teske A, Wawer C, Muyzer G, Ramsing NB (1996) Distribution of sulfate-reducing bacteria in a stratified fjord (Mariager fjord, Denmark) as evaluated by mostprobable-number counts and denaturing gradient gel electrophoresis of PCR-amplified ribosomal DNA fragments. Appl Environ Microbiol 62:1405-1415

Torsvik V, Daae FL, Sandaa RA, Ovreas L (1998) Novel techniques for analysing microbial diversity in natural and perturbed environments. J Biotechnol 64:53-62

Tranvik LJ, Höfle MG (1987) Bacterial growth in mixed cultures on dissolved organic carbon from humic and clear waters. Appl Environ Microbiol 53:482-488

Urbach E, Vergin KL, Young L, Morse A, Larson GL, Giovannoni SJ (2001) Unusual bacterioplankton community structure in ultra-oligotrophic Crater Lake. Limnol Oceanogr 46:557-572

van Hannen EJ, Mooij W, van Agterveld MP, Gons HJ, Laanbroek HJ (1999) Detritus-dependent development of the microbial community in an experimental system: qualitative analysis by denaturing gradient gel electrophoresis. Appl Environ Microbiol 65:2478-2484

von Wintzingerode F, Göbel UB, Stackebrandt E (1997) Determination of microbial diversity in environmental samples: pitfalls of PCR-based rRNA analysis. FEMS Microbiol Rev 21:213-229

Wanner U, Egli T (1990) Dynamics of microbial growth and cell composition in batch cultures. FEMS Microbiol Rev 75:19-44

Weinbauer MG, Höfle MG (1998) Distribution and life strategies of two bacterial populations in a eutrophic lake. Appl Environ Microbiol 64:3776-3783

Wikner J, Hagström Å (1999) Bacterioplankton intra-annual variability: importance of hydrography and competition. Aquat Microb Ecol 20:245-260

Wikner J, Cuadros R, Jansson M (1999) Differences in consumption of allochthonous DOC under limnic and estuarine conditions in a watershed. Aquat Microb Ecol 17:289-299

Zwart G, Crump BC, Agterveld M, Hagen F, Han SK (2002) Typical freshwater bacteria: an analysis of available $16 \mathrm{~S}$ rRNA gene sequences from plankton of lakes and rivers. Aquat Microb Ecol 28:141-155

Zweifel UL, Wikner J, Hagström $\AA$, Lundberg E, Norrman B (1995) Dynamics of dissolved organic carbon in a coastal ecosystem. Limnol Oceanogr 40:299-305 